IP Periodica Polytechnica

Social and Management

Sciences

24(1), pp. 65-73, 2016

DOI: $10.3311 /$ PPso. 7991

Creative Commons Attribution (i)

RESEARCH ARTICLE

\section{Modified Scorecard Method for Evaluating Climate Aspects of Urban Transport Systems}

\author{
Attila Buzási ${ }^{1 *}$, Mária Csete ${ }^{1}$
}

Received 18 February 2015; accepted after revision 29 April 2015

\begin{abstract}
Vulnerability of urban transport systems require actions for increasing adaptive capacity of them and for taking steps towards resilient and sustainable urban areas. Since transportation seems to be a largely mitigation-aimed area, moreover there is an imbalance between mitigation and adaptation measures in this sector, this paper focusing on adaptation-oriented indicators regarding urban transportation. For this purpose, a widely used Balanced Scorecard model has been applied by involving anticipated climate impacts and by modifying the base model. The main aim of present study is to develop set of indicators for setting the ground for a future assessment of adaptive capacity of urban transportation sector in Hungarian cities.
\end{abstract}

\section{Keywords}

urban transport, indicator, scorecard

\section{Introduction}

Transport systems in urban areas is a key contributor to GHG emissions (IEA, 2013), hence it plays a significant role in urban mitigation and adaptation not only in the future but also in present (Dhakal, 2010; Eisenack et al., 2012). Significant proportion of the total energy-related $\mathrm{CO} 2$ emissions in the world originate from transport sector (Török, 2009; Pérez-Martínez, 2012), consequently mitigation strategies greatly affect it and significant changes can be reached by cutting GHG emissions (IPCC, 2014b). It can be stated that cities are not only affected by climate change, but they also contribute to it (Balaban, 2013; Bobylev, 2013, IPCC, 2014a; Csete and Horváth, 2012). Urban transport sector is critical with regards to operation of a given city, therefore it has a pivotal role in creating mitigation and adaptation measures (Mehrotra et al., 2011).

Transportation sector plays a crucial role in socio- economic development by contributing the flow of humans, goods and availability of services moreover by consuming huge amount of fossil fuels (Szlávik and Csete, 2012). One of the main element of climate-resilient cities is less vulnerable, consequently more adaptive society which consumes less energy, protects natural resources, moreover is able to respond to changed climate features in a resilient way. Such a society can be constructed by urban regeneration projects what is fundamentally significant in achieving resilient, therefore sustainable transport systems in urban areas (Balaban, 2013; Dulal et al., 2011).

Beside these, inadequately planned transport systems may result negative local impacts and global consequences, such as increasing air pollution, climate- related impacts on infrastructure, more frequent congestions and decreasing road safety (Bakker et al., 2014; Griskeviciene et al., 2013). Above mentioned impacts and consequences can generate such a complex set of problems, where potential solutions are critical regarding efficient and resilient future operation of cities.

Studies regarding the interdependence between transport sector and climate change mainly focusing on mitigation instead of adaptive capacity or vulnerability (IPCC, 2014a). Urban transport systems are used by huge amount of people in a largely concentrated way, consequently these systems are

\footnotetext{
${ }^{1}$ Department of Environmental Economics, Faculty of Economic and Social Sciences, Budapest University of Techology and Economics, Magyar tudósok krt. 2., H-1117 Budapest, Hungary 
significantly vulnerable regarding changing weather events. The economic role of urban transport systems through moving goods and people require paying more attention on building, restructuring and maintaining highly adaptive systems, as a prerequisite of achieving sustainable urban transport and cities. Transport infrastructure in cities is relevant not only in operating public and individual transport, but also in maintaining emergency services in case of disaster events and evacuation.

Building and maintaining adaptive and resilient urban transport system is a key part of a sustainable city what can ensure global sustainability. Indicators should be used for understanding processes from the present to the future, and for defining relevant actors and actions in terms of resiliency and sustainability goals. Sustainable urban transportation as an important element of urban sustainability can only be reached by evaluating weaknesses and strengthens in light of future challenges for achieving urban sustainability. It can be noted that involving climate-related indicators into urban transport indices is a key step for achieving urban sustainability, since climateresilience can be seen as a part of general sustainability.

Present study does not aim to interpret the whole urban adaptive capacity or mitigation opportunities, only focusing on transportation sector based on the above mentioned importance of it. The main aim of this study is to develop set of indicators by using scorecard approach for setting the ground for a future evaluation of adaptive capacity of urban transport system in Hungarian cities.

\section{Mitigation in urban transport sector}

Since transport sector is one of the main contributors to GHG emissions in urban areas, mitigation measures are inescapable regarding climate-oriented studies (Moeinaddini et al., 2012). Beside this importance of mitigation concerning transportation, it must be emphasized that mitigation and adaptation measures inextricably connected in aiming to create comprehensive and future-oriented urban climate plans. The main aim of adaptation strategies is decreasing urban vulnerability, whilst mitigation measures are seeking to reduce GHG emissions via different actions in given sectors (Reckien et al., 2014).

However the focus of adaptation and mitigation measures is different regarding urban transportation sector, but efficient adaptation strategy is not possible without significant amount of GHG emission by developing mitigation. Through these assumptions, the remainder of the chapter provide a short literature review of mitigation measures in transportation sector, setting the ground for considerations with regards to adaptation opportunities what is in the heart of present study.

Javid (2014) suggested three mitigation strategies regarding road transportation: reducing $\mathrm{CO} 2$ emissions per kilometre by improving fuel-, and energy-efficiency of vehicles and by using future-oriented planning measures; avoiding using personal cars by applying financial solutions (fuel and road taxes), by facilitating the use of public transit and non-motorized transportation modes; replacing fossil fuels by developing and using clean-fuel vehicles. Haghshenas and Vaziri (2012) identified the increasing vehicle-use as the major contributor of transport-related environmental degradation in urban areas. Mitigation options are related to the supply side of urban transportation, however demand side is also relevant in maintaining the functions of transportation infrastructure. The most mitigation opportunities are existing in the following areas: reduction of fuel carbon intensity; reduction of energy intensity; achieving compact urban form and improved infrastructure; finally reduction of journey distances (IPCC, 2014b).

Yedla et al. (2005) also argued the importance of travel demand, vehicle capacity and vehicle stock, as main focus points regarding mitigation strategies in urban transport sector. Similar factors have been appeared by Pérez-López et al. (2013) who identified average daily traffic, average fleet age and vehicle size as main contributors to the amount of emitted GHGs from Spanish motorways in the period of 2005-2010. According to the authors, the first step in reducing GHG level is creating an emission inventory that is a basis of elaborating effective overarching actions that need to be taken. Moreover they argued that motorways are significant parts of urban transport systems due to the extensive and rapid flow of goods and humans, adaptation strategies have to pay special attention to these infrastructure elements. This latter finding shows the strong relevancy of mitigation considerations and actions in effective and comprehensive adaptation actions (Walsh et al., 2011; Reckien et al., 2014; Chappin and van der Lei, 2014).

Dulal et al. (2011) emphasized the role of urban planning in transport-oriented mitigation strategies, since vehicle-use can be decreased, use of public transport can be increased, therefore air pollution and congestions can be prevented or at least reduced by integrating climate-related actions into the planning stage. Apart from these direct impacts, other co-benefits can be available such as decrease of health costs and energy dependency or poverty reduction. Since the marginalized groups are the most susceptible and vulnerable regarding climate change, these above mentioned adaptation co-benefits could be available by developing comprehensive urban transport adaptation strategies and by improving urban adaptive capacity.

Ong et al. (2011) stated that identification of emission sources and emitted amounts of GHGs is crucial in mitigation strategies, since emissions from road transport heavily worsen urban air quality and enhance global warming. For this purpose COPERT mathematical model was applied that takes fuel consumption, travel activity, driving patterns and climatic features into consideration in modelling emission patterns. Finally they suggested mitigation strategies concerning urban transportation, such as passenger car and motorcycles shift to public transport and passenger cars renewal. 
Regarding the possible actions in reducing GHG emissions from road transport Bakker et al. (2014) suggested ASI-model that is based on avoid-shift-improve approach, namely avoiding travel demands, shifting from motorized to non-motorized and less harmful transport modes and improving environmental performance via increase of engine effectiveness.

Finally, transport can be treated as a completely mitigationaimed area concerning huge amount of publications. However available solutions are greatly based on similar aspects, such as shifting from motorized to non-motorized transport modes or improving engine efficiency. Based on widely studied feature of the topic it can be noted that mitigation measures on urban transport systems seem to be over studied, therefore following chapters focusing on adaptation solutions and related indicators for assessing adaptive capacity.

\section{Adaptation in urban transport sector}

As it was mentioned above, transport sector in urban areas is greatly threatened by climate change every region in the world and it accounts for a disproportionate amount of GHG emissions. However, many studies emphasise the importance and opportunity of this sector in mitigation actions (LeQuere et al. 2009; Dhakal, 2010; IEA, 2012), urban transport has potentials in adaptation strategies by providing affordable, resilient and sustainable services to urban dwellers.

The imbalanced importance of mitigation actions in transport sector has been proven by Reckien et al. (2014) who collected 200 urban climate plans from Europe for comparing and studying them. Nearly $90 \%$ of collected mitigation strategies included transport-oriented actions, therefore the transportation has appeared as one of the most frequently mentioned sector beside energy issues and buildings. However mobility issues has not been mentioned separately among adaptation strategies, although ,urban planning and development” subsector may include actions regarding the increase of resiliency of transportation infrastructure.

Jabareen (2013) raised a question on what should cities do for being more resilient and identified vulnerability as the lack of climate-related adaptive capacity. Based on urban transportation system, this absence can threat the essential elements with regards to the operation of cities, consequently it increases vulnerability of whole urban system. According to Mehrotra et al. (2011) vulnerability of urban transport system is mainly depending on the urban fabric, diverse resources and the geographical location of a given transport system whether it is affected by heavy storms, floods or heat waves.

The European Topic Centre on Air and Climate Change summarised the climatic threats and grouped them into vulnerable subsystems regarding urban areas (ETCACC, 2010) based on divergent reports. According to this summary, transportation sector will be influenced by rising temperature and heatwaves; pluvial and fluvial flooding; heavy precipitation and storm surges; and wind storms. Urban transport sectors, and the whole city systems are facing new challenges for achieving sustainability and resiliency due to the changing magnitude of weather events and the new existing features. However there is no detailed and comprehensive analysis concerning quantified climate impacts on urban transport sector (IPCC, 2014b).

IPCC (2014a) identified the most relevant infrastructure elements of urban transport systems affected by climate change in the followings: roads, rail systems and shipping. Climaterelated assessments of roads are focusing on their durability, such as paved road degradation due to extreme warming and the decrease of icy days, when the already observed and anticipated weather extremes exceed the planning thresholds. Bridges play a significant role in road systems, but the predicted damages entail huge amount of economic consequences without implementing adaptation actions. In case of rail systems, changing weather may cause damages through thermal expansion, moreover underground rail systems may be affected by increased cooling demand. The increase of cooling capacity of underground in London requires $\$ 290$ million investment in the near future for maintaining its services due to the predicted warming in the city (BSR, 2014). Bobylev (2013) emphasized that urban railway system can be endangered by accumulation of ice, since supporting electricity lines easily can be broken down, therefore operation of rails, trolleys and trams can be heavily hindered.

Related to economic losses, Jonkeren et al. (2014) argued that extreme low water level causes economic consequences, such as increasing prices in inland waterway transport system. During the extremely dry summer in 2003 inland waterway sector had to face $€ 480$ mio. losses in North West Europe. Since cities are founded mainly along important trade routes, therefore rivers and other inland waterways have significant impact in the life of a given city not only from economic but also from environmental point of view. Consequently the lack of effective and appropriate adaptation strategy can entail economic loss in urban transport sector due to the extreme heatwaves, storms and changing precipitation patterns.

In spite of the relevance of economic assessment of adaptation policies and actions, comparability of adaptation costs are highly limited due to the differences between cities, amounts and sectors concerned in strategies and plans, since there is a lack of comprehensive and widely accepted methodology with regards to the assessment of costs (UN-HABITAT, 2011).

Interconnectivity of urban transport systems can easily cause domino effect, so creating efficient and well- developed adaptation strategies are crucial, therefore collapse of such transport systems can be prevented (ETCACC, 2010). Avoiding this potential collapse, it is needed: to create high-quality public transport; to develop alternative routes; to determine critical infrastructure elements.

Bobylev (2013) distinguished four different strategies regarding elements of urban infrastructure as the basis of transportation 
system: integration of adaptation measures into planning stage; taking the flexibility of urban physical infrastructure into consideration in planning and construction stage; mainstreaming adaptation actions into existing regulation, building codes and norms; broader management considerations regarding operation of urban infrastructure. He focused on components of physical infrastructure including roads, bridges, pipelines, electricity and telecommunication lines, which are supporting the operation of cities, consequently they are the basis of urban transport systems.

Considering adaptive capacity, Carter et al. (2015) suggested a wide-range involvement of stakeholders in decision-making processes, and this statement is extremely relevant regarding transportation in urban areas, since this system is used by billion of people every day. Moreover calculation with adaptation costs is an important part of financial issues, and constitutes to build capacity for urban adaptation. As Tyler and Moench (2012) suggested, public information is relevant for covering broader range of urban population, who shall be more aware regarding the interdependence between urban subsystems and anticipated climate changes.

Based on the collected and studied recent publications with regards to adaptive capacity and vulnerability of urban transport systems it can be stated that economic and other social status highly affect adaptive capacity of a given city. Since transportation sector is based on urban infrastructures, above mentioned assumption means that wealthier cities have more resilient urban systems. However this correlation can be contested, since freezing rain occurred in December of 2014 in Budapest affected the 12nd district in the most heavily way and caused serious damages although per capita income is one of the largest in the above mentioned district of the Hungarian capital. Consequently it could be expected that vulnerability of the district is far less than other neighbourhoods of Budapest, although exposure and sensitivity of it heavily affected the outcomes and the amount of economic losses. Therefore it cannot been clearly declared that better economic status entails higher resiliency in a given city concerning all types of weather extremes, however more financial opportunities shall play a crucial role in preventing serious damages.

Beside the economic issues, institutions have a crucial role in creating climate-resilient urban areas, since a more aware urban population means more resilient and less vulnerable society which is the base of a sustainable city, because there is no sustainability without climate resiliency and reversely, there is no resiliency without sustainability. Clearly defined mitigation and adaptation actions in terms of anticipated weather forecasts are the main parts of effective urban planning (Buzási, 2014), hence well collected, selected and applied indicators can help in decision making processes in identifying key strengthens and weaknesses, moreover opportunities, challenges and barriers.

In summary, building and maintaining an adaptive and resilient urban transport system is a key part of a sustainable city what can ensure global sustainability. Indicators should be used for understanding processes from the present to the future, and for defining relevant actors and actions in terms of resiliency and adaptation goals. Resilient urban transportation as an important element of urban sustainability can only be reached by evaluating weaknesses and strengthens in light of future challenges for developing less vulnerable and more adaptive cities. Based on these assumptions, it can be declared that decision makers shall pay more attention on how to decrease climate-related vulnerability in urban areas from planning and strategy-making point of view.

Based on high importance of adaptation solutions regarding urban systems, a customised methodology and related set of indicators have been elaborated in the following chapters.

\section{Methodology}

It was mentioned above that infrastructure elements are largely threaten by changing climate patterns, therefore there is a need to pay more attention on them with regards to adaptive capacity of urban transport systems. Beside the infrastructure, vehicles and passengers are also threaten by extreme weather events, therefore assessment of adaptive capacity of them are pivotal in evaluating urban transport systems regarding anticipated weather events. Using indicators is a similar and popular way of assessing different features of a given city and a well-grounded methodology used worldwide. Based on simplicity of it, the main aim of this paper is to collect indicators for evaluating adaptive capacity of urban transport systems by using information-driven approach completed with scorecards to identify targets and sources of the variables.

Applied methodology is slightly different from existing methods in international studies, however based on Balanced Scorecard (BSC) (Kaplan and Norton, 1992; Mendes et al., 2012; Buys et al., 2014; Guimaraes et al., 2010) and a modified Scorecard (SC) (Cruz and Marques, 2014) systems from different scientific area. Common features of the above mentioned studies are the illustration of cause-effect interdependency, the increasing need for illustrating given features of a given system. Moreover present methodology and consequences based on it can be interpreted as both strategic and decision making supporting tool, like the BSC method. This latter feature of the methodology can be seen through the use of indicators that provide useful information for decision- makers and planners about the climate-resiliency of transport sector in a given city. Although BSC methodology is used mainly in the business sector (Rohm and Montgomery, 2011), it is easily applied for the purpose of present study by customizing the following details:

- eliminating the weights of the indicators and perspectives;

- indicators grouped by climate impacts instead of client, internal processes, learning and growth and financial perspectives;

- including potential sources of the indicators; 
- taking climate impacts into consideration as the main factor in selecting strategies.

As it was declared by Kaplan and Norton (1992), businessoriented BSC models are focusing on clients and four aspects of the business environment, such as clients, internal processes, learning and growth and financial perspectives. However this feature can be posed as a relevant difference compared to present application, the contradiction can be resolved. In present interpretation of client orientation, population of a given city can be treated as clients who the climate-resilient transport sector is operating for. Therefore the client perspective is appearing in this approach, since cities shall meet urban dwellers' needs for developing resilient transport system. Internal processes perspective is also involving into the framework through maintenance services by making budget-limited actions for maintaining less vulnerable infrastructure elements, such as roads, bridges and rails. Additional measures, such as early warning systems of discovering errors in their early phase are concerning to the internal processes. Finally, the learning and growth perspective can be translated to the institutional actions in planning and creating resilient cities through

- climate-oriented planning exercises on infrastructure,

- monitoring risks, exposure and vulnerability,

- developing strategies and building standards.

Figure 1 shows the framework of the methodology and logic used in present study. It can be seen that the identified vision of developing resilient urban transport system is in the top. Related strategy for reaching it is affected by climate change and potential impacts, therefore involving climate variables provide a mix of different strategies due to the different impacts of a given climate event. In case of increasing temperature there is a need for more strength infrastructure elements and cooling solutions in vehicles or in case of heavy storms and floods more resistant solutions shall be needed. Related actions and indicators can be found on the bottom of the framework which is common to the BSC method by using variables to assess the results of a given strategy in lights of a given changing weather pattern. It can be stated that involving climate impacts into planning state entails more diverse strategies, consequently modifying BSC method seems to be proved.

However the original BSC methodology has been modified for the purpose of our study, it can be noted that client-, internal processes-, and growth and learning- oriented perspectives can be involved into this framework by defining BSC aspects as the parts of a given urban subsystem in terms of being resilient regarding adverse effects of climate change.

Measuring adaptive capacity of transport sector in Hungary is not unprecedented, since Szendrö et al. (2014) conducted a research in this topic. They applied a data- driven approach in developing a set of indicators, which means the selection of

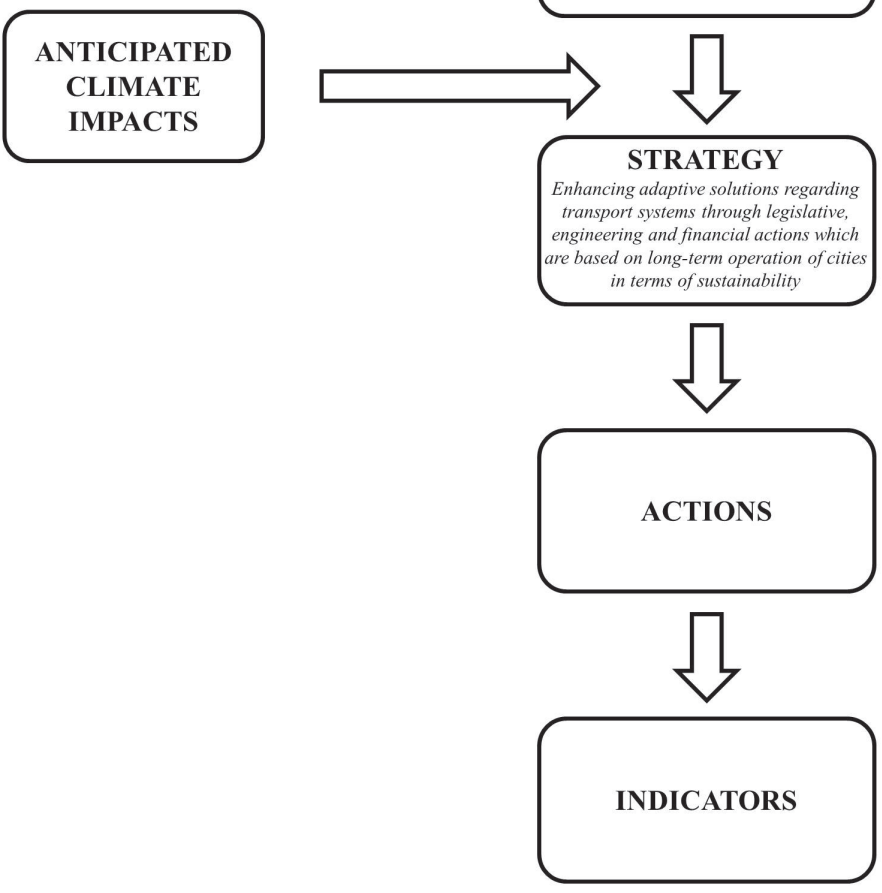

Fig. 1 Involving climate impacts into the BSC framework and logic

variables is based on data availability. This approach is applied most frequently in recent studies, however it has been changed into information-driven indicator selection method in this study, when data availability is not taken into consideration. Hence applied indicators can be seen as potential recommendations for improving the explanatory features of the selected indicators. Moreover determining potential sources of the indicators can help in collecting data with regards to adaptive capacity of urban transportation; therefore information-driven approach can be transformed into a data-driven solution.

\section{Indicators}

In this chapter selected indicators are introduced in the following tables based on scorecard methodology, completed with potential sources of them. As it was mentioned in the previous section, present application of indicators is BSC-based, however it does not contain all aspects of BSC approach, rather focusing on urban population as the clients of sustainable and climate- friendly cities. Moreover in parallel with above mentioned modifications regarding BSC and scorecard methodologies, present approach does not concern to service maintainers and municipalities, only in meeting the needs with regards to input data for assessing the resiliency of the urban transport subsystem. However it can be noted that these simplifications provide opportunities in further analyses to involve other sectors and subsystems in order to all aspects of resiliency in urban areas. Since the aim of this study is to provide set of indicators regarding resilient urban transport systems, SC method has 
been slightly modified, because there are no target and performance values. However required direction of a given change has been showed, so based on this approach, concrete values can be defined for applying indicators in assessing the climateoriented performance of urban transportation in a given city. For this practical purpose, submitting possible sources of indicators shall support planners and decision makers in assessing and controlling climate-based processes, therefore involving these sources into the tables below is essential.

As it was mentioned above, the defined comprehensive vision is to develop resilient urban transport system. For achieving this, related strategy has been determined: enhancing adaptive solutions regarding transport systems through legislative, engineering and financial actions which are based on long-term operation of cities in terms of sustainability. Indicators are grouped by two different approach, firstly whether a given indicator is related to a given climate impact, such as higher temperature and heat waves, fluvial and pluvial floods, and more intensive storms as well.

The selection of negative impacts is based on Bartholy et al. (2007) who identified warming and changing precipitation patterns as the most significant changes in the Carpathian basin for 2071-2100. Consequently heat waves and water-related challenges endanger urban transport systems in an unprecedented way and reduce resiliency of both urban population and the mentioned systems.

Since variables concern to the adaptive capacity of Hungarian urban transport systems, e.g. rising sea level, as potential impacts has not been involved into the study. The second approach in grouping indicators is whether a given indicator is technical-, or institutional-oriented. In case of latter, variables have not been grouped by climate impacts, since they concern all of anticipated weather extremes.

Table 1 shows the identified indicators regarding higher temperature and heat waves, completed with the targets and potential sources of them. Variables of this category concern the increased heat stress and related consequences regarding infrastructure elements and vehicles. Heat-resistant public transport vehicles are crucial in terms of sustainable operation of a given city, since as it was mentioned above in case of London, where heat problems in underground system cause significant amount of economic losses.

Further considerations regarding roads, rails and public transport stations have been taken into the study. Shading bike lanes, sidewalks and railway stations are a pivotal part of adapting transport infrastructure systems to the changing temperature patterns (ETCACC, 2010). Potential sources of the indicators are the public transport company and the municipality as the maintainers of the affected systems.

Table 2 includes indicators concerning floods what can be fluvial (due to the inadequacy of the underground rain water systems) and pluvial (due to the overflow of a given river).
Table 1 Identified indicators regarding higher temperature and heat waves

\begin{tabular}{|c|c|c|}
\hline Indicator & Target & Source \\
\hline $\begin{array}{c}\% \text { of public transport vehicles } \\
\text { equipped with } \mathrm{AC}\end{array}$ & $\uparrow$ & Public transport comp. \\
\hline $\begin{array}{c}\% \text { of roads softening during } \\
\text { heatwaves }\end{array}$ & $\downarrow$ & Municipality \\
\hline$\%$ of shaded bike lanes & $\uparrow$ & Municipality \\
\hline$\%$ of shaded sidewalks & $\uparrow$ & Municipality \\
\hline$\%$ of shaded railway stations & $\uparrow$ & Public transport comp. \\
\hline $\begin{array}{c}\text { No. of days exceeding } 25^{\circ} \mathrm{C} \text { in the } \\
\text { underground }\end{array}$ & $\downarrow$ & Public transport comp. \\
\hline $\begin{array}{l}\text { Frequeny of maintenance of inland } \\
\text { waterways }\end{array}$ & $\uparrow$ & Municipality \\
\hline $\begin{array}{l}\% \text { of tined windows in public } \\
\text { transport vehicles }\end{array}$ & $\uparrow$ & Public transport comp. \\
\hline$\%$ of heat resistant rails & $\uparrow$ & Public transport comp. \\
\hline
\end{tabular}

Table 2 Identified indicators regarding fluvial and pluvial floods

\begin{tabular}{ccc}
\hline Indicator & Target & Source \\
\hline $\begin{array}{c}\text { No. of inland ports with flood- } \\
\text { protection equioments }\end{array}$ & $\uparrow$ & Municipality \\
\hline$\%$ of road in floodplain & $\downarrow$ & Municipality \\
\hline $\begin{array}{c}\text { \% of drainage system constructed } \\
\text { in lights of increased capacity }\end{array}$ & $\uparrow$ & Municipality \\
\hline $\begin{array}{l}\text { \% of corrosionresistant traffic lights } \\
\text { and signs }\end{array}$ & $\uparrow$ & Municipality \\
\hline $\begin{array}{c}\text { \% of porous pavement and road } \\
\text { Capacity of emergency pumping } \\
\text { system in the underground systems }\end{array}$ & $\uparrow$ & Municipality \\
\hline $\begin{array}{c}\text { \% of underground stations pro- } \\
\text { tected from floods and inundations }\end{array}$ & $\uparrow$ & Public transport comp. \\
\hline
\end{tabular}

Since changing precipitation patterns can cause significant damages in Hungary (Bartholy, 2007) through more intensive and dangerous floods in Hungarian cities. As it was mentioned above by Jonkeren et al. (2014) inland waterways are heavily affected by changing climate, therefore a port-related indicator has been involved into the collected set of indicators. Maintaining operation of public transport services is crucial due to the flows of people and the role in disaster management, therefore two indicators are related to the underground systems what is the most vulnerable component of the urban transportation concerning flooding.

Table 3 identifies variables regarding impacts of intensive storms on the urban adaptive capacity. Infrastructure elements 
Table 3 Identified indicators regarding more intensive storms

\begin{tabular}{ccc}
\hline Indicator & Target & Source \\
\hline \% of broken overhead lines & $\downarrow$ & Supplier \\
\hline Storm-resistant bridges & $\uparrow$ & Municipality \\
\hline signs of storm-resistant traffic lights and & $\uparrow$ & Municipality \\
\hline road & $\uparrow$ & Municipality \\
\hline $\begin{array}{c}\text { She of higher strength pavement and } \\
\text { storms in public transport stops }\end{array}$ & $\uparrow$ & Public transport comp. \\
\hline $\begin{array}{c}\text { No. of wind fences along open railways } \\
\text { \% of overhead lines equipped with } \\
\text { circuit breaker protection }\end{array}$ & $\uparrow$ & Public transport comp. \\
\hline $\begin{array}{c}\text { \% } \\
\text { roting pedestrians from }\end{array}$ & & Public transport comp. \\
\hline
\end{tabular}

are largely threaten by storms, hence decrease of their vulnerability is crucial in maintaning the services provided by them. As it can be seen, suppliers have appeared as potential sources regarding two indicators in terms of overhead lines. According to this comprehensive and overarching cooperation is essential between municipalities, public transport companies and other suppliers to achieve less vulnerability in a given city. Therefore collection of the indicators contributes to the launch of the work to step towards a more resilient urban system.

As it was mentioned previously in the beginning of the chapter, selected variables have been grouped by two perspectives, therefore Table 4 includes indicators regarding institutional dimension which are mainly qualitative ones. These indicators are related to legislative actions by developing building and construction standards, by preparing emergency services to disaster events, by developing early warning systems. Two of the indicators involved in Table 4 concern to vulnerability of infrastructure elements, however they require legislative solutions to tackle the disturbances due to extreme weather events. In these cases, the frequency of bridge maintenance per year and the no. of newly generated asphalt rutting per year are quantitative indicators (signed by the direction of the given target) beside their qualitative backgrounds. Since most of the variables presented in Table 4 are qualitative ones, required target - signed by "Yes" - is concerning to the existence of a given institutional action. The responsibility of data service is divided between the given municipality and the public transport company, as the maintainer and the operator of the given urban transport system.

\section{Conclusion}

Based on the review of the literature regarding mitigation and adaptation solutions in urban transport sector it can be stated that mitigation-oriented actions and related indicators exceed the amount of adaptation ones. However there is a need of a mix
Table 4 Identified institutional-oriented indicators

\begin{tabular}{|c|c|c|}
\hline Indicator & Target & Source \\
\hline Dedicated lanes during disaster events & Yes & Municipality \\
\hline $\begin{array}{l}\text { Changing speed limits based on } \\
\text { extreme weather events }\end{array}$ & Yes & Municipality \\
\hline $\begin{array}{c}\text { Passenger evacuation plans for } \\
\text { underground }\end{array}$ & Yes & Public transport comp. \\
\hline $\begin{array}{c}\text { Emergency strategy to evacuation } \\
\text { routes }\end{array}$ & Yes & Public transport comp. \\
\hline $\begin{array}{l}\text { Heat-resistant road and railway } \\
\text { contruction design standards }\end{array}$ & Yes & $\begin{array}{l}\text { Municipality; } \\
\text { Public transport comp. }\end{array}$ \\
\hline $\begin{array}{l}\text { Emergency strategies concerning } \\
\text { operation of public transport system }\end{array}$ & Yes & Public transport comp. \\
\hline $\begin{array}{l}\text { Building standards regarding } \\
\text { climate extremes }\end{array}$ & Yes & Municipality \\
\hline $\begin{array}{c}\text { Frequency of bridge maintenance } \\
\text { per year }\end{array}$ & $\uparrow$ & Municipality \\
\hline $\begin{array}{c}\text { No. of newly generated asphalt rutting } \\
\text { per year }\end{array}$ & $\downarrow$ & Municipality \\
\hline Risk-mapping, vulnerability-mapping & Yes & Municipality \\
\hline Early warning system & Yes & $\begin{array}{l}\text { Municipality; } \\
\text { Public transport comp. }\end{array}$ \\
\hline $\begin{array}{l}\text { Climate-related public procurement } \\
\text { regarding public transport fleet }\end{array}$ & Yes & $\begin{array}{l}\text { Municipality; } \\
\text { Public transport comp. }\end{array}$ \\
\hline $\begin{array}{c}\text { Flexible infrastructure design } \\
\text { concerning transport infrastruscture }\end{array}$ & Yes & $\begin{array}{l}\text { Municipality; } \\
\text { Public transport comp. }\end{array}$ \\
\hline
\end{tabular}

of adaptation and mitigation measures in order to enhance effectiveness, therefore the most optimal solution can be achieved. One of the main challenges of climate-oriented planning is to develop such a transport system in cities what can meet general needs in non-disaster periods, moreover to be able to maintain the most important functions if disaster events occur.

It can be stated that future-oriented adaptation policies what incorporate regional or local climate forecasts into different projects can prevent such infrastructure investments taken place in potentially dangerous areas regarding climate disasters. For this purpose adaptation- oriented set of indicators has been developed for the future assessment of adaptive capacity of Hungarian urban transport systems by modifying BSC methodology. The classic BSC model was completed by the main anticipated climate impacts, therefore indicators have been grouped by them.

Using SC methodology with the potential sources allow the decision makers to transform existing data- driven approach into information-driven one, thus data availability can be increased by potential cooperation between maintainers and operators of transport infrastructure elements and vehicles. 


\section{Acknowledgement}

This study was supported by the János Bolyai Research Scholarship of the Hungarian Academy of Sciences.

\section{References}

Bakker, S., Zuidgeest, M., de Coninck, H., Huizenga, C. (2014) Transport, Development and Climate Change Mitigation: Towards an Integrated Approach. Transport Reviews. 34 (3). pp. 335-355. DOI: $10.1080 / 01441647.2014 .903531$

Balaban, O. (2013) The Use of Indicators to Assess Urban Regeneration Performance for Climate- Friendly Urban Development: The Case of Yokohama Minato Mirai 21. In: Kawakami, M. et al. (eds.) Spatial Planning and Sustainable Development: Approaches for Achieving Sustainable Urban Form in Asian Cities, Strategies for Sustainability. Springer Netherlands. pp. 91-115. DOI: 10.1007/978-94-007-5922-0_6

Bartholy, J. (2007) Regional climate change expected in Hungary for 20712100. Applied Ecology and Environmental Research. 5 (1). pp. 1-17. DOI: 10.15666/aeer/0501_001017

Bobylev, N. (2013) Urban Physical Infrastructure Adaptation to Climate Change. In: Saulnier, J. B., Varella, M. D. (eds.) Global Change, Energy Issues and Regulation Policies, Integrated Science \& Technology Program 2. DOI: 10.1007/978-94-007-6661-7_4

BSR (2014) Climate Change: Implications for Transport. [Online] Available from: http://www.bsr.org/reports/BSR-Cambridge-Climate- ChangeImplications-for-Transport.pdf [Accessed: 3th January 2015]

Buys, L., Mengersen, K., Johnson, S., van Buuren, N., Chauvin, A. (2014) Creating a Sustainability Scorecard as a predictive tool for measuring the complex social, economic and environmental impacts of industries, a case study: Assessing the viability and sustainability of the dairy industry. Journal of Environmental Management. 133. pp. 184-192. DOI: 10.1016/j.jenvman.2013.12.013

Buzási, A. (2014) Will Budapest be a climate-resilient city? - Adaptation and mitigation challenges and opportunities in development plans of Budapest. European Journal of Sustainable Development. 3 (4). pp. 277-288. DOI: 10.14207/ejsd.2014.v3n4p277

Carter, J., Cavan, G., Connelly, A., Guy, S., Handley, J., Kazmierczak, A. (2015) Climate change and the city: Building capacity for urban adaptation. Progress in Planning. 95. pp. 1-66. DOI: 10.1016/j.progress.2013.08.001

Chappin, E., van der Lei, T. (2014) Adaptation of interconnected infrastructures to climate change: A socio-technical systems perspective. Utilities Policy. 31. pp. 10-17. DOI: 10.1016/j.jup.2014.07.003

Cruz, N., Marques, R. (2014) Scorecards for sustainable local governments. Cities. 39. pp.165-170. DOI: 10.1016/j.cities.2014.01.001

Csete, M., Horváth, L. (2012) Sustainability and green development in urban policies and strategies. Applied Ecology and Environmental Research. 10 (2). pp. 185-194. DOI: 10.15666/aeer/1002_185194

Dhakal, S. (2010) GHG emissions from urbanization and opportunities for urban carbon mitigation. Current Opinion in Environmental Sustainability. 2 (4). pp. 277-283. DOI: 10.1016/j.cosust.2010.05.007

Dulal, H., Brodnig, G., Onoriose, C. (2011) Climate change mitigation in the transport sector through urban planning: A review. Habitat International. 35 (3). pp. 494-500. DOI: 10.1016/j.habitatint.2011.02.001

Eisenack, K., Stecker, R., Reckien, D., Hoffmann, E. (2012) Adaptation to climate change in the transport sector: a review of actions and actors. Mitigation and Adaptation Strategies for Global Change. 17 (5). pp. 451-469. DOI: 10.1007/s11027-011-9336-4
ETCACC (2010) Adapting Urban Transport to Climate Change. Module 5f. In: Sustainable Transport: A Sourcebook for Policy-makers in Developing Cities. [Online] Available from: http://www.sutp.org/component/ phocadownload/categ ory/53-5f?download=112:5f-acc-en [Accessed: 3th January 2015]

Griskeviciene, D., Griskevicius, A., Griskeviciute- Geciene, A. (2012) A New Approach to Assessment of Infrastructure Projects on Urban Transport Systems. Transport and Telecommunication. 13 (2). pp. 108-122. DOI: $10.2478 / \mathrm{v} 10244-012-0009-5$

Guimarães, B., Simões, P., Marques, R. (2010) Does performance evaluation help public managers? A Balanced Scorecard approach in urban waste services. Journal of Environmental Management. 91 (12). pp. 26322638. DOI: 10.1016/j.jenvman.2010.07.039

Haghshenas, H., Vaziri, M. (2012) Urban sustainable transportation indicators for global comparison. Ecological Indicators. 15 (1). pp. 115-121. DOI: 10.1016/j.ecolind.2011.09.010

IEA (2012) World Energy Outlook. [Online] Available from: http://www. iea.org/publications/freepublications/publication/WEO2012_free.pdf [Accessed: 4th January 2015]

IEA (2013) A Tale of Renewed Cities - A policy guide on how to transform cities by improving energy efficiency in urban transport system. [Online] Available from: from: http://www.iea.org/publications/freepublications/ publi cation/Renewed_Cities_WEB.pdf [Accessed: 4th January 2015]

IPCC (2014a) Climate Change 2014: Impacts, Adaptation, and Vulnerability. Part A: Global and Sectoral Aspects. Contribution of Working Group II to the Fifth Assessment Report of the Intergovernmental Panel on Climate Change. Cambridge, New York: Cambridge University Press.

IPCC (2014b) Climate Change 2014: Mitigation of Climate Change. Contribution of Working Group III to the Fifth Assessment Report of the Intergovernmental Panel on Climate Change. Cambridge. New York: Cambridge University Press.

Javid, R., Nejat, A., Hayhoe, K. (2014) Selection of CO2 mitigation strategies for road transportation in the United States using a multi-criteria approach. Renewable and Sustainable Energy Reviews. 38. pp. 960-972. DOI: 10.1016/j.rser.2014.07.005

Jabareen, Y. (2013) Planning the resilient city: Concepts and strategies for coping with climate change and environmental risk. Cities. 31. pp. 220-229. DOI: $10.1016 /$ j.cities.2012.05.004

Jonkeren, O., Rietveld, P., van Ommeren, J., te Linde, A. (2014) Climate change and economic consequences for inland waterway transport in Europe. Regional Environmental Change. 14 (3). pp. 953-965. DOI: 10.1007/s10113-013-0441-7

Kaplan, R. S., Norton, D. P. (1992) The balanced scorecard: measures that drive performance. Harvard Business Review. 70 (1). pp. 71-80.

LeQuere, C., Raupach, M. R., Canadell, J. G., Marland, G., Bopp, L., Ciais, P., Conway, T. J., Doney, S. C., Feely, R. A., Foster, P. (2009) Trends in the sources and sinks of carbon dioxide. Nature Geoscience. 2. pp. 831-836. DOI: 10.1038/ngeo689

Mehrotra, S., Lefevre, B., Zimmerman, R., Gerçek, H., Jacob, K., Srinivasan, S. (2011) Climate change and urban transportation systems. In: Rosenzweig, C., Solecki, W. D., Hammer, S. A., Mehrotra, S. (eds.) Climate Change and Cities: First Assessment Report of the Urban Climate Change Research Network. Cambridge: Cambridge University Press. pp. 145-177. DOI: 10.1017/cbo9780511783142.012

Mendes, P., Santos, A., Perna, F., Ribau Teixeira, M. (2012) The balanced scorecard as an integrated model applied to the Portuguese public service: a case study in the waste sector. Journal of Cleaner Production. 24. pp. 20-29. DOI: 10.1016/j.jclepro.2011.11.007 
Moeinaddini, M., Asadi-Shekari, Z., Zaly Shah, M. (2012) The effectiveness of private motorized trips indicators in redudcing car usage. IJTTE. 2 (4). pp. 347-358. DOI: $10.7708 /$ ijtte.2012.2(4).05

Ong, H., Mahlia, T., Masjuki, H. (2011) A review on emissions and mitigation strategies for road transport in Malaysia. Renewable and Sustainable Energy Reviews. 15 (8). pp. 3516-3522. DOI: 10.1016/j.rser.2011.05.006

Pérez-López, P., Gasol, C., Oliver-Solà, J., Huelin, S., Moreira, M., Feijoo, G. (2013) Greenhouse gas emissions from Spanish motorway transport: Key aspects and mitigation solutions. Energy Policy. 60. pp. 705-713. DOI: $10.1016 /$ j.enpol.2013.04.075

Reckien, D., Flacke, J., Dawson, R., Heidrich, O., Olazabal, M., Foley, A., Hamann, J., Orru, H., Salvia, M., De Gregorio Hurtado, S., Geneletti, D., Pietrapertosa, F. (2014) Climate change response in Europe: what's the reality? Analysis of adaptation and mitigation plans from 200 urban areas in 11 countries. Climatic Change. 122 (1-2). pp. 331-340. DOI: $10.1007 / \mathrm{s} 10584-013-0989-8$

Rohm, H., Montgomery, D. (2011). Link Sustainability to Corporate Strategy Using the Balanced Scorecard. [Online] Available from: http://www.balancedscorecard.org/portals/0/pdf/linkingsustainabilitytocorporatestrategyusingthebalancedsco recard.pdf [Accessed: 4th January 2015]

Szendrő, G., Csete, M., Török, Á. (2014) The Sectoral Adaptive Capacity Index of Hungarian Road Transport. Periodica Polytechnica Social and Management Sciences. 22 (2). pp. 99-106. DOI: 10.3311/ppso.7377
Szlávik, J., Csete, M. (2012) Climate and Energy Policy in Hungary. Energies. 5 (12). pp. 494-517. DOI: 10.3390/en5020494

Török, Á. (2009) Greenhouse gas emission of Hungarian transport sector. Periodica Polytechnica Transportation Engineering. 37 (1-2). pp. 65-69. DOI: $10.3311 /$ pp.tr.2009-1-2.11

Tyler, S., Moench, M. (2012) A framework for urban climate resilience. Climate and Development. 4 (4). pp. 311-326.

DOI: $10.1080 / 17565529.2012 .745389$

UN-HABITAT (2011) Citites and Climate Change: Global Report on Human Settlements 2011. [Online] Available from: http://unhabitat. org/?wpdmact=process\&did=NDM0L mhvdGxpbms [Accessed: 4th January 2015]

Yedla, S., Shrestha, R., Anandarajah, G. (2005) Environmentally sustainable urban transportation - comparative analysis of local emission mitigation strategies vis-à-vis GHG mitigation strategies. Transport Policy. 12 (3). pp. 245-254. DOI: 10.1016/j.tranpol.2005.02.003

Walsh, C., Batty, M., Zanni, A., Barr, S., Carney, S., Bristow, A., Ford, A., Dagoumas, A., Harpham, C., Watters, H., Hall, J., Tight, M., Dawson, R. (2011) Assessment of climate change mitigation and adaptation in cities. Proceedings of the ICE - Urban Design and Planning. 164 (2). pp. 75-84. DOI: 10.1680/udap.2011.164.2.75 